\title{
Pengaruh Penggunaan Sosial Media Instagram Dimasyarakat Kampung Kandaga
}

Sandi Gustiandi ${ }^{1}$, Tedi Kurniadi ${ }^{2}$, Ahmad Rianda Lubis ${ }^{3}$, Neng Aas Fauziah Rohmah ${ }^{4}$

1,2,3.4 Program Studi IImu Komunikasi, Fakultas IImu komunikasi, Universitas Islam Nusantara

\begin{tabular}{|c|c|}
\hline ARTICLE INFO & ABSTRACT \\
\hline Article history: & \multirow{4}{*}{$\begin{array}{l}\text { Path occupies the fourth position with the dominance of users ranging } \\
\text { in age from } 20 \text { to } 25 \text { years. We will conduct research in the form of a } \\
\text { survey. The survey is a quantitative basic form". The object of this } \\
\text { research is "The Influence of Instagram Social Media Use in the } \\
\text { Kandaga Village community". Researchers conducted a survey on the } \\
\text { influence of Instagram social media use in the Kandaga village } \\
\text { community. Our group used a survey with questionnaire research } \\
\text { which was used to collect research data containing questions and } \\
\text { statements answered by respondents. In addition, other words of } \\
\text { influence are a state of reciprocity, or a causal relationship between } \\
\text { what affects and what is influenced. The Internet significantly } \\
\text { influences the way people live by changing because of its technology. } \\
\text { We get There are } 12 \text { informants who use Instagram among teenagers } \\
\text { and we asked some questions regarding the influence of Instagram } \\
\text { media. There are } 80 \% \text { of them prefer to interact with friends face to face } \\
\text { or directly and } 70 \% \text { of them get information and insight from them. he's } \\
\text { the instagram. }\end{array}$} \\
\hline $\begin{array}{r}\text { Received Sep 19, } 2021 \\
\text { Revised Sep 24, } 2021 \\
\text { Accepted Jan 24, } 2021\end{array}$ & \\
\hline \multirow{4}{*}{$\begin{array}{r}\text { Keywords: } \\
\text { Influence; } \\
\text { Instagram social media; } \\
\text { Kandaga village; } \\
\text { Survey method. }\end{array}$} & \\
\hline & \\
\hline & ABSTRAK \\
\hline & $\begin{array}{l}\text { Path menduduki keempat dengan dominasi pengguna direntang usia } \\
20 \text { tahun sampai dengan } 25 \text { tahun. Kami akan melakukan penelitian } \\
\text { berupa survey. Survey merupakan bentuk dasar kuantitatif". Objek } \\
\text { penelitian ini adalah "Pengaruh Penggunaa Sosial Media Instagram } \\
\text { dimasyarakat Kampung Kandaga". Peneliti melakukan survey pada } \\
\text { pengaruh penggunaan sosial media Instagram dimasyarakat kampung } \\
\text { kandaga Kelompok kami menggunakan survey dengan penelitian } \\
\text { kuesioner yang digunakan mengumpulkan data penelitian dengan } \\
\text { didalamnya berisi pertanyaan dan pernyataan yang dijawab oleh } \\
\text { responden. Selain itu, kata lain dari pengaruh adalah suatu keadaan } \\
\text { ada hubungan timbal balik, atau hubungan sebab akibat antara apa } \\
\text { yang mempengaruhi dengan apa yang di pengaruhi. Internet secara } \\
\text { signifikan mempengaruhi cara orang hidup dengan berubah karena } \\
\text { teknologinya. Kami mendapatkan } 12 \text { informan yang menggunakan } \\
\text { istagram di kalangan remaja dan kami memberikan beberapa } \\
\text { pertanyaan terkait pengaruhnya media istagram. Ada } 80 \% \text { dari mereka } \\
\text { lebih memilih berinteraksi dengan teman secara tatap muka atau } \\
\text { langsung dan } 70 \% \text { dari mereka mendapatkan informasi dan wawasan } \\
\text { dari media instagram tersebut. }\end{array}$ \\
\hline
\end{tabular}

This is an open access article under the CC BY-NC license.

Corresponding Author:

Sandi Gustiandi

Program Study IImu Komunikasi,Fakultas IImu Komuniksi,

Universitas Islam Nusantara

Jl. Soekarno-Hatta No.530, Sekejati, Kota Bandung, Jawa Barat 40286

Email: sandigustiandi1@gmail.com 


\section{PENDAHULUAN}

Menurut Michael Cross, (2013) Media sosial adalah sebuah istilah yang menggambarkan bermacam-macam teknologi yang digunakan untuk mengikat orang-orang ke dalam suatu kolaborasi, saling bertukar informasi, dan berinteraksi melalui isi pesan yang berbasis web. Dikarenakan internet selalu mengalami perkembangan, maka berbagai macam teknologi dan fitur yang tersedia bagi pengguna pun selalu mengalami perubahan. Hal ini menjadikan media sosial lebih hypernym dibandingkan sebuah referensi khusus terhadap berbagai penggunaan atau rancangan,

Menurut The ABC, (2011) Media sosial membungkus perangkat digital yang memungkinkan terjadinya kegiatan komunikasi dan berbagi melintasi jaringan. Media sosial digunakan secara produktif oleh seluruh ranah masyarakat, bisnis, politik, media, periklanan, polisi, dan layanan gawat darurat (Rahadi, 2017). Media sosial telah menjadi kunci untuk memprovokasi pemikiran, dialog, dan tindakan seputar isu-isu sosial. Perkembangan teknologi pada era modern ini tidaklah mengherankan (Rafsanjani, 2018). Salah satu perkembangangannya adalah perangkat yang sudah ada sejak perang dunia II sampai sekarang (indoworx, 2018). Dampak positif dari perkembangan teknologi informasi tesebut membuat komunikasi antar manusia tidak dibatasi lagi oleh waktu dan biaya yang mahal.

Setiap platform media sosial memiliki fungsi yang hampir sama namun memiliki keunggulan masing-masing. Menurut Iswah, (2011) menjelaskan bahwa media sosial pada umumnya digunakan pengguna internet (internet user) sebagai sarana menjalin komunikasi kepada pungguna lain dalam bentuk postingan atau konten-konten berbagi yang dibagikan oleh pemilik akun media sosial. Konten tersebut dapat berupa video, foto, e-book, dan lainnya. Kontenkonten yang dibagikan pengguna media sosial beragam jenisnya. Ada konten yang memuatmuatan pribadi atau personal matter seperti membagi foto pernikahannya, ulang tahun kerabat atau upacara kelulusan seperti wisuda (Ita Suryani et al., 2020). Konten yang besifat edukasi juga tidak kalah banyak. Kegunaan media sosial bagi sebagian pengguna internet adalah menonton video, membagi ulang postingan orang lain, menempatkan selfi, dan membagi foto makanan (Adhil, 2021).

Menurut Sosial Memos (2016) mengadakan penelitian pada akhir tahun 2016 mengenai media sosial apa saja yang paling banyak digunakan oleh masyarakat indonesia pada tahun 2016. Facebook menduduki peringkat pertama dan tercatat sebanyak sebanyak 11.658 .760 pengguna dengan rentang usia 16 tahun sampai usia 35 tahun. Instagram menduduki peringkat kedua dengan didminasi oleh pengguna dengan rentang 16 tahun samapi dengan 25 tahun. Twitter menduduki peringkat ketiga karena setiap harinya pengguna internet di indonesia memposting 2,4\% tweet dan 10.6 juta tweet perharinya di seluruh dunia. Path menduduki keempat dengan dominasi pengguna direntang usia 20 tahun sampai dengan 25 tahun. Menurut Ptimack, (2017) kepemilikan media sosial tidak terbatas pada kaum menengah ke atas yang memiliki akses internet dan perangkat yang mendukung, tidak pula terbatas umur, jenis kelamin, dan suku. Sebagian besar orang yang berada di era digital memiliki setidaknya satu atau dua media sosial.

Menurut M Nisrina, (2015:137) Instagram adalah sebuah aplikasi yang digunakan untuk membagi-bagikan foto dan vidio. Instagram sendiri masih merupakan bagian dari facebook yang memungkinkan teman facebook itu mengikuti kita dalam akun sosial media instagram(Soraya, 2017). Makin populernya instagram sebagai aplikasi yang digunakan untuk membagi foto mengakibatkan banyak pengguna yang terjun ke ranas bisnis seperti akun sosial bisnis yang turut mempromosikan produk-produknya lewat instagram (Damayanti \& Pamungkas, 2018). Instagram adalah bentuk dari salah satu media jejaring sosial yang dapat dimanfaatkan sebagai media pemasaran langsung, melalui instagram produk atau jasa dapat ditawarkan dengan menguploadfoto atau vidio singkat, sehingga para calon konsumen dapat melihat jenis-jenis barang atau jasa yang ditawarkan.

Masyarakat modern saat ini hampir tidak mungkin terkena paparan media. Disadari atau tidak, media dengan segala kontennya hadir menjadi bagian hidup manusia (Watie, 2016). Seiring dengan perkembangan jaman, kehadiran media makin beragam dan bekembang (Waruwu et al., 2020). Awalnya komunikasi dalam media berjalan hanya searah, dalam arti penikmat media hanya bisa menikmati konten yang disajikan sumber media. Namun seiring perkembangan jaman, orang awam sebagai penikmat media tidak lagi hanya bisa menikmati konten dari media yang terpapar 
padanya, namun sudah bisa ikut serta mengisi konten dimedia tersebu. Muncul dan berkembangnya internet membawa cara berkomunikasi baru dimasyarakat. Media sosial hadir dan merubah paragdigma berkomunikasi dimasyarakat saat ini (Watie, 2016). Komunikasi tak terbatas jarak, waktu, ruang. Bisa terjadi dimana saja, kapan saja, tanpa harus tatap muka.

Menurut Baidu, (2014) masyarakat informasi diidentifikasi dengan jumlah media yang dikonsumsi. Dibuktikan dengan beredarnya arus informasi yang begitu pesat disekitar mereka. Selain itu, kini informasi tidak hanya dibuat oleh institusi media tertentu, tetapi semua kalangan masyarakat pun mempunyai kesempatan yang sama untuk memproduksi dan mempublikasikan sebuah informasi (Widiastuti, 2016). Mengingat perkembangan teknologi informasi dan komunikasi yang terus berinovasi sehingga memudahkan pengguna untuk melakukannya (Sumintono et al., 2012). Berkat teknologi baru seperti internet segala kebutuhan manusia dapat dipenuhi (Prawiradilaga, 2016). Mulai dari kebutuhan untuk bersosialisasi, mengakses informasi sampai kepada pemenuhan hiburan. Kini, kehadirannya lebih dimanfaatkan sebagai media sosial oleh masyarakat.

Peneliti akan meneliti di daerah kp. Kandaga Desa. Sukasari Kec. Pameungpeuk Kab. Bandung, karena di daerah ini sangat terasa pengaruh media sosial apa lagi di zaman ini yang semuanya tidak di perbolehkan keluar kecuali ada hal yang sangat penting jadi meningkatnya media sosial di kalangan masyarakatnya. Semua serba susah menjalani aktifitas seperti biasa seperti sekolah, kerja, maupun aktifitas lainnya. Karena serba di rumah semua aktivitas tersebut di ganti dengan kerja di rumah atau work for home dengan mengunakan media sosial bahkan sekolah pun di ganti dengan sekolah online dengan bantuan media sosial. Tidak bisa di pungkiri lagi media sosial sangatlah penting buat masyarakat untuk melakukan aktivitas tersebut dan pengaruh dari media sosialnya pun sangatlah tinggi karena banyaknya sosialisasi menggunakan media sosial bahkan beriteraksinya pun menggunakan media sosial dan hilangnya sosialisasi tatap muka yang bisa di bilang lebih gampang untuk di lakukan.

Di daerah Kp. Kandaga pun kebanyakan masyarakatnya beraktifitas keluar rumah untuk bekerja dan sekolah karena pandemi seperti ini semua hal itu dikurangi dan di gantikan serba online dan kami sangat ingin meneliti lebih lanjut lagi pengaruh dari media sosial yang saat ini sering di gunakan oleh masyarakat Kp. Kandaga ini. Sakin serba di rumah banyak masyarakat menggunkan media yang sangat mempengaruhi kelangsungan hidupnya mereka bekerja menggunkan media sosial istagram dikarenkan disana sangat gampang untuk melakukan pekerjaan seperti bejualan produk karena luasnya jejaring medianya bahkan ada juga anak-anak yang bersekolah untuk mengerjakan tugasnya melalui media istagram seperti membuat video dan di share melalui media sosial istagram untuk mengerjakan tugasnya. Istagram juga gampang untuk di akses oleh siapapun yang ingin menggunakan masyarakat Kp. Kandaga pun menggunakan media istagram untuk melakukan hal-hal yang bisa membuat kelangsungan hidupnya meskipun banyak orang yang lanjut usia kesusahan mengunakan istagram tetapi anaknya yang biasa mengunakan media istagram membantu orang yang lanjut usia supaya bisa melakukan kegiatannya demi kelangsungan hidupnya.

\section{METODE PENELITIAN}

Kami akan melakukan penelitian berupa survey. Penelitian survei merupakan suatu bentuk aktifitas yang sudah menjadi kebiasaan pada masyarakat, dan banyak diantaranya berpengalaman dengan riset ini sebagai suatu bentuk yang tersendiri atau yang lainnya. Survey riset dikembangkan sebagai bentuk pendekatan positivist pada ilmu-ilmu sosial (Adiyanta, 2019). Sebagaimana dikatakan oleh Robert Groves, seorang ahli survey terkemuka, "survey menghasilkan informasi yang secara alami bersifat statistik". Survey merupakan bentuk dasar kuantitatif"(Benuf \& Azhar, 2020). Penelitian survey menanyakan kepada beberapa responden tentang kepercayaannya, pendapat-pendapat, karakteristik, dan perilaku yang telah atau sedang terjadi, Robert M. Groves, Survey Methodology (2010). Survey menyediakan pertanyaanpertanyaan untuk penelitian tentang laporan keyakinan atau kepercauaan atau perilaku diri. Pertanyaan-pertanyaan tersebut menjadi lebih tajam ketika responden meberikan jawabanjawaban atas suaru pertanyaan dengan variable-variabel yang dikehendaki.

Objek penelitian ini adalah "Pengaruh Penggunaa Sosial Media Instagram dimasyarakat Kampung Kandaga". Peneliti melakukan survey pada pengaruh penggunaan sosial media 
Instagram dimasyarakat kampung kandaga. Kampung kandaga adalah sebuah kampung yang bertempatan di desa sukasari kota bandung yang sekaligus kami jadikan sebagai subjek penelitian kami. Pengaruh penggunaan sosial media instagram di masyarakat kampung kandaga merupakan suatu yang diakibatkan oleh sesuatu yang dilakukan, bisa positif atau negatif atau bisa menjadi pengaruh yang kuat Membawa konsekuensi positif dan negatif (Novianti, 2019). Pengaruh positifnya penggunaan sosial media insntagram dikampung kandaga yaitu memudahkan pengguna untuk mendapatkan informasi terbaru, seperti informasi tentang hiburan, akal sehat, gaya hidup terkini, informasi terkini dan berita terbaru. Sedangkan pengaruh negatifnya penggunaan sosial media dimasyarakat kampung kandaga yaitu mereka kurang percaya diri dengan penampilan mereka, jadi cenderung meniru konten di Instagram, kurangnya pengawasan penggunaan Instagram juga menyebabkan terganggunya waktu dalam berkomunikasi dengan lingkungan sekitar dan khawatir mengurangi waktu belajar, dan mengkonsumsi informasi yang tidak pantas akan mempengaruhi eksistensi dimasyarakat kampung kandaga yang berlebihan misalnya suka pamer barang atau kekayaan dan kesombongan.

\section{HASIL DAN PEMBAHASAN}

Kelompok kami menggunakan survey dengan penelitian kuesioner yang digunakan mengumpulkan data penelitian dengan didalamnya berisi pertanyaan dan pernyataan yang dijawab oleh responden. Seperti yang dipaparkan oleh Suharsimi, Arikunto (1998) "Metode polling adalah metode pengumpulan data dengan mengisi daftar pertanyaan sehingga dapat diketahui data dari pengetahuan, sikap dan pendapat".

Tabel1. Hasil keseluruhan pengaruh penggunaan sosial media instagram dimasyarakat kampung kandaga dari 12 informan

\begin{tabular}{|c|c|}
\hline Persen & Keterangan \\
\hline $100 \%$ & Pengguna instagram \\
\hline $83 \%$ & Sudah menggunakan instagram dengan bijak atau baik \\
\hline $94 \%$ & Ada perubahan setelah menggunakan instagram \\
\hline $60 \%$ & $\begin{array}{l}\text { Setelah menggunakan instagram sering ingin meniru orang lain dan } \\
\text { memperaktekannya (selama dalam hal positif atau baik) }\end{array}$ \\
\hline $80 \%$ & $\begin{array}{l}\text { Lebih baik bersosialisasi dengan teman itu bertatap muka daripada } \\
\text { mengggunkan instagram }\end{array}$ \\
\hline $70 \%$ & $\begin{array}{l}\text { Keuntungan yang didapat dari instagram adalah mengetahui informasi dan } \\
\text { menambah wawasan }\end{array}$ \\
\hline $85 \%$ & $\begin{array}{l}\text { Solusi untuk menjadi bijak bersosial media dalam penggunaan instagram } \\
\text { yaitu berpikir sebelum berbicara atau mengomentari, merenung sebelum } \\
\text { bertindak, menelaah sebelum menghakimi dan membagikan hal-hal yang } \\
\text { positif }\end{array}$ \\
\hline
\end{tabular}

Penelitian ini di fokuskan di daerah Kandaga karena mayoritasnya remajanya pengguna media sosial Instagram, jadi penelitian kami mengfokuskan apakan remaja di daerah Kandaga sudah mengerti pengaruh dari media sosial tersebut. Kami telah mendapatkan informan sebanyak 12 orang remaja yang berumur $20 \mathrm{~s} / \mathrm{d} 25$ tahun di daerah Kandaga, kami menanyakan beberapa pertanyaan tentang penggunaan media sosial instagram.

Presentasi dari informan di berikan pertanyaan Apakah kamu pengguna media instagram? dan kami mendapatkan hasil $100 \%$ dari 12 informan adalah pengguna media sosial instagram, dari hasil tersebut bisa dinyatakan bahwa remaja di daerah Kandaga adalah pengguna media sosial instagram. Pertanyaan selanjutnya yang di berikan kepada beberapa informan yaitu Apakah kamu sudah menggunkan secara bijak atau baik? kami mendapatkan hasil $83 \%$ telah menggunakan instagram secara bijak atau baik dan 17\% dari 12 informan belum menggunakan secara bijak atau baik. Dari hasil presentasi tersebut bisa dinyatakan bahwa remaja di daerah Kandaga tidak sepenuhnya atau tidak semua telah menggunkan instagram dengan baik atau 
bijak di karenakan sebagian dari informan mengakses sosial media sekadar mengikuti tren atau gaya di masa sekarang.

Pertanyaan selanjutnya Apakah ada perubahan yang di rasakan setelah menggunakan instagram? hasil yang kami dapat ada $94 \%$ dari informan merasakan perubahan setelah menggunakan instagram dan $6 \%$ tidak merasakan perubahan setalah menggunkan instagram dari hasil yang kami dapat bisa di simpulkan bahwa remaja di daerah Kandaga telah merasakan perubahan dari hidup mereka setelah menggunakan instagram dan sisanya tidak merasakan perbedaan sama sekali karena mereka lebih gampang mendapatkan informasi dari media sosial dan berinteraksi melalui media sosial dan sisanya yang tidak merasakan perubahan di karenakan mereka lebih nyaman berinteraksi tatap muka langsung tanpa media dan sekedar mengakses seperlunya saja.

Pertanyaan selanjutnya Setelah menggunakan instagram, Apakah kamu sering ingin meniru orang lain dan mempraktekannya? dari pertanyaan tersebut kami mendapatkan $60 \%$ dari 12 informan meniru orang lain dari media instagram dan $40 \%$ tidak meniru orang lain di media sosial, dari hasil tersebut dapat di simpulkan bahwa $60 \%$ dari informan mengikuti orang lain di media sosial dan mengikuti gaya hidup yang lagi populer di media sosial dan sisanya $40 \%$ tidak mengikuti gaya yang sedang populer di media dan tidak meniru apa yang orang lain perbuat.

Pertanyaan selanjutnya Menurut kamu lebih baik menggunakan instagram untuk bersosialisasai bersama teman atau tatap muka? dari pertanyaan tersebut kami mendapatkan $80 \%$ memilih bertatap muka dan $20 \%$ sisanya memilih bersosilisasi lewat media, dapat di simpulkan bahwa remaja memilih untuk bertatap muka dan bersosialisasi dengan teman dan kerabat sisanya memilih untuk berinteraksi lewat media di karena di zaman pandemi seperti ini berinteraksi susah bahkan bertemu dengan teman atau sodara yang jauh agak sulit jadi ketika tidak adanya pandemi seperti ini remaja di daerah Kandaga memilih untuk bertatap muka secara langsung.

Pertanyaan selanjutnya Apa yang kamu dapat dari instagram atau keuntungan bagi anda? dari pertanyaan tersebut kami mendapatkan $70 \%$ telah mendapatkan keuntungan dari media sosial instagram dan $30 \%$ belum mendapatkan keuntungan dari presentasi tersebut lebih banyak remaja yang telah mendapatkan keuntungan dari media sosial instagram seperti informasi, wawasan, dan bisa mengobrol dengan sodara atau teman yang jauh dan sisanya belum mendapatkan keuntungan karena mereka menggunakan instagram sekedar mengisi waktu luang saja.

Pertanyaan selanjutnya Menurut kamu pribadi solusi untuk menjadi bijak dalam bersosial media khususnya instagram bagaimana? dari pertanyaan yang terakhir ini kami mendapatkan $85 \%$ dari 12 informan memberikan solusi yang baik seperti tidak di gunakan media sosial ke halhal negatif, berfikir sebelum bertindak, memposting hal-hal yang bermanfaat bagi banyak orang, dan tidak menyebarkan berita palsu atau hoax. Dan 15\% sisanya hanya memberikan solusi yang bisa di bilang datar seperti jika suka maka tiru kalo tidak suka jangan di ambil atau buang jauh jauh. Bisa di simpulkan remaja di daerah kandaga memberikan informasi atau solusi yang cukup baik bagi orang rang yang belum menggunkan media sosial dengan baik atau bijak.

Pengaruh menurut Kamus Besar Bahasa Indonesia (KBBI) adalah daya yang ada dan timbul dari sesuatu (orang, benda) yang ikut membentuk watak, kepercayaan atau perbuataan seseorang. Dari pengertian di atas telah dikemukakan sebelumnya bahwa pengaruh adalah merupakan sesuatu daya yang dapat membentuk atau mengubah sesuatu yang lain. Pada zaman sekarang, hal hal yang mempngaruhi kehidupan manusia adalah kebutuhan hidunya itu sendiri. Terbukti dari bagaimana kita sebagai manusia yang hakikatnya memegang dan mengndalikan masa depan tetapi malah kita yang di kendalikan oleh masa depan. Selain itu, kata lain dari pengaruh adalah suatu keadaan ada hubungan timbal balik, atau hubungan sebab akibat antara apa yang mempengaruhi dengan apa yang di pengaruhi. Dua hal ini adalah yang akan dihubungkan dan dicari apa ada hal yang menghubungkannya. Di sisi lain pengaruh adalah berupa daya yang bisa memicu sesuatu, menjadikan sesuatu berubah. Maka jika salah satu yang disebut pengaruh tersebut berubah, maka akan ada akibat yang ditimbulkannya (CAHYONO, 2016). Sosial media atau New media merupakan media yang menawarkan digitisation, convergence, interactiviy, dan development of network terkait pembuatan pesan dan penyampaian pesannya. Kemampuanya menawarkan interaktifitas ini memungkinkan pengguna dari new me- 
dia memiliki pilihan informasi apa yang dikonsumsi, sekaligus mengendalikan keluaran informasi yang dihasilkan ser-ta melakukan pilihan-pilihan yang diinginkannya. (Watie, 2011).

Internet dan budaya di Indonesia memiliki konsekuensi di mana membutuhkan waktu bertahun-tahun untuk diterapkan sepenuhnya. Internet secara signifikan mempengaruhi cara orang hidup dengan berubah karena teknologinya. Misalnya, individu telah mengubah topik dan cara komunikasi, frekuensi, dan kebiasaan mereka sebagai akibat dari ketersediaan dan aksesibilitas alat komunikasi online. Perkembangan teknologi informasi komunikasi dan efek globalisasi yang luas mengubah cara suatu masyarakat hidup, berinteraksi, belajar, dan mendefinisikan kembali ide identitas budaya. Konsep ruang, waktu, dan jarak kehilangan makna konvensionalnya. Sayangnya, manfaat ini juga bisa dipandang sebagai kelemahannya di mana terdapat globalisasi budaya dan gerakan global dari proses budaya yang sedang berlangsung (Muchammad Bayu Tejo Sampurno, 2020)

Adapun dalam Ramadhani (2013) dampak positif sosial media adalah: (a). Mempermudah kegiatan belajar, karena dapat digunakan sebagai sarana untuk berdiskusi dengan teman sekolah tentang tugas (mencari informasi). (b). Mencari dan menambah teman atau bertemu kembali dengan teman lama. Baik itu teman di sekolah, di lingkungan bermain maupun teman yang bertemu melalui jejaring sosial lain. (c). Menghilangkan kepenatan pelajar, itu bisa menjadi obat stress setelah seharian bergelut dengan pelajaran di sekolah. Misalnya: mengomentari status orang lain yang terkadang lucu dan menggelitik, bermain game, dan lain sebagainya.

Selain dampak positif sosial media juga memiliki dampak negatif terhadap pendidikan anak. Adapun dampak-dapak negatif yang ditimbulkan sosial media adalah: (a). Berkurangnya waktu belajar, karena keasyikan menggunakan sosial media seperti terlalu lama ketika facebookkan dan ini akan mengurangi jatah waktu belajar; (b). Mengganggu konsentrasi belajar di sekolah, ketika siswa sudah mulai bosan dengan cara pembelajaran guru, mereka akan mengakses sosial media semaunya; (c). Merusak moral pelajar, karena sifat remaja yang labil, mereka dapat mengakses atau melihat gambar porno milik orang lain dengan mudah; (d). Menghabiskan uang jajan, untuk mengakses internet dan untuk membuka facebook jelas berpengaruh terhadap kondisi keuangan (terlebih kalau akses dari warnet) sama halnya mengakses facebook dari handphone; (e). mengganggu kesehatan, terlalu banyak menatap layar handphone maupun komputer atau laptop dapat mengganggu kesehatan mata.

\section{KESIMPULAN}

Kami meneliti di daerah Kandaga dan mencari beberapa informan yang menggunakan media istagram. Kami mendapatkan 12 informan yang menggunakan istagram di kalangan remaja dan kami memberikan beberapa pertanyaan terkait pengaruhnya media istagram. Dari 12 informan yang kami wawancara ada $100 \%$ penggunakan istagram dan dari semua informan ada $83 \%$ sudah menggunkan instagram dengan bijak. 94\% dari informan sudah merasakan perubahan setelah menggunakan instagram dan $60 \%$ dari mereka menirukan apa yang ada di instagram tapi dalam hal yang baik atau positif. Ada $80 \%$ dari mereka lebih memilih berinteraksi dengan teman secara tatap muka atau langsung dan $70 \%$ dari mereka mendapatkan informasi dan wawasan dari media instagram tersebut. $85 \%$ dari mereka sudah mendapatkan pelajaran dari instagram seperti jangan asal berkomentar, membagikan ilmu yang mereka dapat dari instagram supaya bisa membagikan hal-hal yang baik, dan tidak menghakimi orang-orang di media sosial. Dari semua yang kami dapat remaja di daerah kandaga telah terpengaruh oleh media sosial instagram dalam hal yang positif seperti mendapatkan informasi dan wawasan, berprilaku dengan baik walaupun lewat media. Bahkan di pademi saat ini mereka berinteraksi lewat media mesikpun mereka lebih nyaman bertatap muka langsung. Meskipun belum sepenuhnya mereka bertindak bijak menggunakan jejaring sosial media tatapi mereka sudah mengetahi apa yang buruk dan yang baik di media sosial dengan kata lain pengaruh dari media sosial instagram sangatlah terasa tetapi mereka menggunakannya dengan bijak.

\section{Referensi}

Adhil, S. D. (2021). law enforcement against criminal acts of a youtuber through the use of social media based on the ITE Law 11 of 2008 Article 36, Article 45 paragraph 1 and Article 51 paragraph 2 regarding the case study of ferdian paleka in the Bandung District Court. Universitas Darul Ulum. 
Adiyanta, F. C. S. (2019). Hukum dan studi penelitian empiris: Penggunaan metode survey sebagai instrumen penelitian hukum empiris. Adminitrative Law \& Governance Journal, 2(4), 697-709.

Benuf, K., \& Azhar, M. (2020). Metodologi penelitian hukum sebagai instrumen mengurai permasalahan hukum kontemporer. Gema Keadilan, 7(1), 20-33.

BIBLIOGRAPHY V 1033 Memos, S. (2016). Digital In 2017 : GLOBAL OVERVIEW. Hootsuite. hIm 3

BIBLIOGRAPHY $\backslash 1033$ Baidu. (2014). Jelajah dunia dimobile Indonesia. . Baidu indonesia

CAHYONO, A. S. (2016). PENGARUH MEDIA SOSIAL. Pournal Publiciana, 142.

Damayanti, E., \& Pamungkas, I. N. A. (2018). Konten Digital Marketing Melalui Instagram Warteg Hipster Sebagai Upaya Membangun Brand Awareness. EProceedings of Management, 5(1).

Ita Suryani, L., Handar, M., \& Ekasuci, R. (2020). PEMANFAATAN MEDIA SOSIAL SEBAGAI MEDIA PROMOSI BAGI RADIO MERSI 93.9 FM. Journal Komunikasi, 11(1).

Iswah. (2011). Panduan Praktis Mengoptimalkan Twitter. Jakarta: Mediakita

Muchammad Bayu Tejo Sampurno, T. C. (2020). Budaya Media Sosial, Edukasi Masyarakat dan Pandemi. Jurnal Sosial dan Budaya Syar-i, 533

Novianti, E. (2019). Pemaknaan Nyadaran Sebagai Pelestarian Budaya Pada Etnik Jawa. Dan Dokumentasi Kontemporer.

Prawiradilaga, D. S. (2016). Mozaik Teknologi Pendidikan: E-Learning. Kencana.

Primack. (2017). Use of multiple social media platforms and symptoms of depression and anxiety: $A$ nationally-representative study among U.S. young adults. Computers in Human Behavior. U.S Amerika. 69,1-9.

Rafsanjani, B. (2018). Sikap tabayyun dalam al-qur'an menurut mufassir dan kontekstualisasi pada problematika pemberitaan media sosial. UIN Sunan Ampel Surabaya.

Ramadhani, Z. B. (2013). Dampak Positif dan Negatif Situs Jejaring Sosial Media di Kalangan Remaja. Makalah Perkembagan Teknologi.

Michael, C. (2013). Leveraging Social Networking While Mitigating Risk: 1st Edition, Syngress.

Rahadi, D. R. (2017). Perilaku pengguna dan informasi hoax di media sosial. Jurnal Manajemen Dan Kewirausahaan, 5(1), 58-70.

Smart ekonomi kota Tangerang, (indoworx, 2018). Perkembangan teknologi hlm: 2

Soraya, I. (2017). Personal Branding Laudya Cynthia Bella Melalui Instagram (Studi Deskriptif Kualitatif Pada Akun Instagram@ Bandungmakuta). Jurnal Komunikasi, 8(2).

Sumintono, B., Wibowo, S. A., Mislan, N., \& Tiawa, D. H. (2012). Penggunaan teknologi informasi dan komunikasi dalam pengajaran: Survei pada guru-guru sains SMP di Indonesia. Jurnal Pengajaran MIPA, 17(1), 122-131.

Waruwu, M., Arifianto, Y. A., \& Suseno, A. (2020). Peran Pendidikan Etika Kristen dalam Media Sosial di Era Disrupsi. Jurnal Pendidikan Agama Kristen (JUPAK), 1(1), 43-56.

Watie, E. D. S. (2016). Komunikasi dan media sosial (communications and social media). Jurnal The Messenger, 3(2), 69-74.

Watie, E. D. (2011). Komunikasi dan Media Sosial. THE MESSENGER, 70.

Widiastuti, T. (2016). Kepemilikan Media dan Demokrasi di Era Digital Information Age. Prosiding Seminar Nasional INDOCOMPAC. 